\title{
Osteoporosis Prevalence and Nutritional Intake among the People in Farm, Fishing and Urban Districts
}

\author{
Sigetosi Kamiyama, * Satoru Kobayashi,* Shoichi Abe, \\ Eiji Takahashi, Eikichi Wakamatsu ${ }^{\dagger}$ and Tatsuya \\ KURAshina ${ }_{+}^{+}$ \\ Department of Hygiene, Department of Orthopedics, $\dagger$ and \\ Department of Radiology, + Tohoku University School of \\ Medicine, Sendai
}

Kamtyama, S., Kobayashi, S., Abe, S., Takahashi, E., Wakamatsu, E. and Kurasmina, T. Osteoporosis Prevalence and Nutritional Intake among the People in Farm, Fishing and Urban Districts. Tohoku J. exp. Med., 1972, 107 (4), 387-394 _ Direct roentgenograms of dorso-ventral projection were examined on 1,210 subjects in the sixth and seventh decades living in the different environments of farm, fishing and urban districts. The roentgenographic findings were classified into three grades according to osteoporotic changes, and the prevalence of osteoporotic changes was compared by $\chi^{2}$-tests among the districts. The prevalence was higher in the farm districts as compared to those in the fishing and urban districts. The examinees of the two districts, the farm and the fishing, were somatometrically measured of their spinal crookedness, and the results showed that the occurrence of crookedness was higher with concurrent high prevalence of osteoporosis in the farm village. Nutritional survey processed in all the five districts showed the causative difference of habitual food intake among the districts. osteoporosis; spinal crookedness; nutrition

Official reports of the World Health Organization (1967, 1962) indicate that Japan is the country with the highest death rate due to cerebrovascular diseases, and also that Japan is one of the countries where the people take a low calcium diet when compared among countries where a nutritional survey was achieved. Calcium content of river water is also lower in Japan (Kobayashi 1957) than in most European countries. The grades of osteoporotic changes have been thought to be an indication of the different calcium stock in bone tissue (Barnett and Nordin 1960). Thus the prevalence of osteoporotic changes in the different districts would reflect the nutritional status being especially related to the calcium intake. In this paper, the prevalence of osteoporotic changes was compared among the middle aged in different districts with the farm, fishing and urban populations.

\section{Materials and Methods}

Roentgenographic studies were made at each field of the districts together with the multiphasic survey of circulatory system during the summer in 1966 to 1968 . The

Received for publication, February 8, 1972.

* Present address: Department of Hygiene, Alita University School of Medicine, Akita, Japan 
subjects examined were those including both sexes at the ages from 50 to 69 who came to the examination room. Special attention was paid to exclude the cases of secondary malformation of spinal column due to spinal caries and other orthopedic diseases.

The subjects were the residents of a rocky coast fishing village of the Pacific Ocean (Fishing village R), inland rice cultivating farm villages on the east and the west (Farm village $\mathrm{G}, \mathrm{H}$, and $\mathrm{U}$ ) and an urban district on the east (City $\mathrm{S}$ ) of the central mountains of the north-eastern Japan as indicated in Fig. 1.

The roentgenograms were taken by anterioposterior projection in a supine position. A Toshiba KCD-K5RC Model portable X-ray apparatus for mass chest examination (condensor exposure type) was partly remodeled for our purpose. The exposure factors were as follows: $70 \mathrm{KVp}$ at $1 \mu \mathrm{F}$ of condensor capacity, $100 \mathrm{~cm}$ of focus-film distance, 8:1 grid ratio of Bucky X-ray diaphragm, intensifying screen of Kyokko HS, and Fuji medical $\mathrm{X}$-ray films of $\mathrm{KX}$ type.

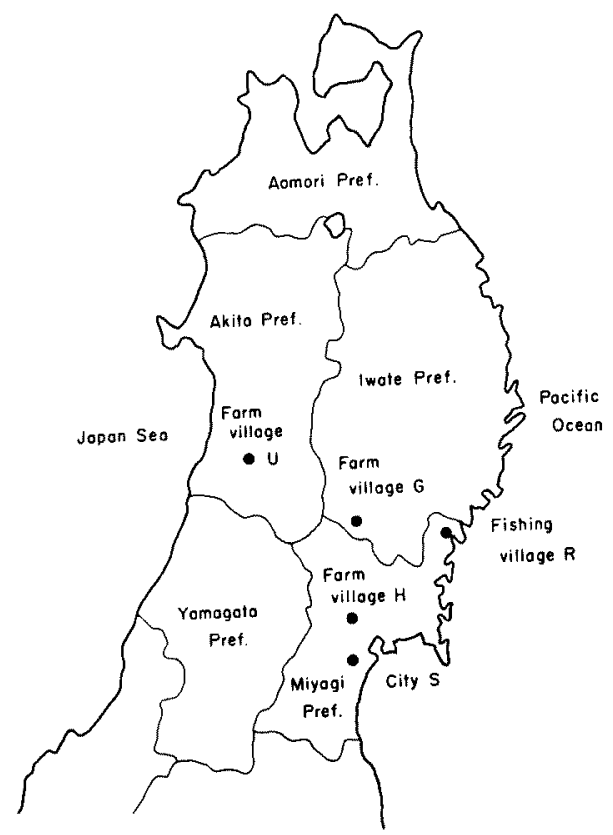

Fig. 1. Location of the survey districts.

The evidence of osteoporosis was entirely based on the radiographic changes of trabecule of the lumbar vertebral bodies. Deformities of the vertebral bodies, arches or processes were not taken into account. The osteoporotic changes were classified into three degrees according to the criteria which have previously been described (Wakamatsu 1966, Kamiyama et al. 1968). The principle of the classification is as follows. The grade 0 is characterized by fine and evenly uniform lattice-work of the trabecular shadows. The grade I is represented by roughly and unevenly distorted lattice-work of trabecular shadow, and called coarse trabecular lattices. The highest grade II is the 'ratten blind' form characterized by disappearance of horizontal trabecular shadow and by shadows of conspicuous hypertrophied trabeculae. Each of these three forms of the roentgenographic change coincides with the microhistometric observation (Wakamatsu et al. 1971). Osteoporosis prevalence was compared in reference to the age and sex in each of the two areas by $\chi^{2}$-tests of $3 \times 2$ tables.

In order to compare the occurrence of the spinal crookedness and elucidate the relationship between the spinal crookedness and osteoporosis in the different districts, the subjects in the fishing village $R$ and the farm village $H$ were anthropometrically measured 
of the spinal crookedness. The spinal curvature from the process prominence of the seventh cervical vertebra to the fourth lumbar spinous process was copied using an adjustable cruve ruler. From the copied curvature, the spinal crookedness was represented by the method described by Abe (1971), in terms of kyphotic or lordotic values, kyphotic or lordotic indices, maximal kyphotic or lordotic positions, and so on for the respective kyphotic and lordotic curvature as shown in Fig. 2. The mean values of these indices of the spinal crookedness were calculated for each group showing osteoporotic changes, and the values obtained for the two districts were compared.

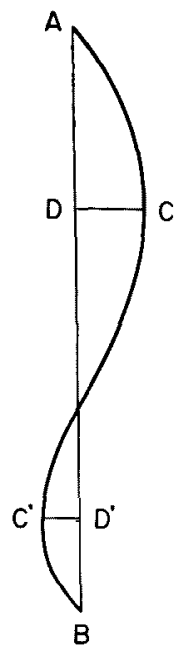

Fig. 2. Legends of the spinal crookendess indices.

A: Prominence of 7 th cervical vertebral spine

B: Prominence of 4 th lumbar vertebral spine

$\mathrm{AB}$ : Distance of the two prominences

$\frac{\mathrm{CD}}{\mathrm{AB}} \times 100:$ Kyphotic index

$\frac{\mathrm{AD}}{\mathrm{AB}} \times 100:$ Maximal kyphotic position

$\frac{\mathrm{C}^{\prime} \mathrm{D}^{\prime}}{\mathrm{AB}} \times 100:$ Lordotic index

$\frac{\mathrm{AD}^{\prime}}{\mathrm{AB}} \times 100:$ Maximal lordotic position

\section{Results}

Osteoporosis prevalence. Table 1 shows the results of examination of all the subjects, being grouped in terms of area, sex and age, and Fig. 3 shows the sexual difference of the above mentioned roentgenographic osteoporotic changes. The percentage of the normal and uniform lattice-work of 0 grade was $27.2 \%$ for male and $28.2 \%$ for female in the city $\mathrm{S} ; 13.8 \%$ and $17.1 \%$ in the fishing village $\mathrm{R}$, $9.9 \%$ and $12.3 \%$ in the farm village $\mathrm{G}$; and $9.6 \%$ and $6.4 \%$ in the farm village $U$ and 7.0 and $5.4 \%$ in the farm village $H$, respectively.

Comparison of the prevalence of osteoporotic changes made by $\chi^{2}$-test of $3 \times 2$ tables for each of the two areas was tabulated in Table 2. The table shows that the incidences of osteoporotic changes are much different according to the districts. Prevalence of osteoporotic changes in the fishing village $\mathrm{R}$ showed significant differences from those in the farm villages $\mathrm{H}$ and $\mathrm{U}$ and in the city $\mathrm{S}(\mathrm{p}<$ 0.005 ) for the total subjects of both sexes. The prevalence in the city $\mathrm{S}$ was also found to be significantly different from those in the other four districts for the total and the male subjects $(p<0.005)$, but as for the female subjects, the difference was not significant between the city $S$ and the fishing village $R$. Among the three farm villages, the differences are not consistent. The prevalence in the village $G$ was significantly lower as compared to the village $H$, but the difference in prevalence was not significant between the villages $G$ and $U$, or between the villages $\mathrm{U}$ and $\mathrm{H}$, for the total subjects and male or female subjects alone. 
TABLE 1. Osteoporosis prevalence in the different districts

\begin{tabular}{l|l|r|r|r|r}
\hline \multirow{2}{*}{ Districts } & \multirow{2}{*}{ Sex } & \multicolumn{4}{|c}{ Osteoporotic change } \\
\cline { 3 - 6 } & & 0 & I & II & Total \\
\hline Fishing & Male & 9 & 53 & 3 & 65 \\
village R & Female & 27 & 111 & 19 & 157 \\
& Total & 36 & 164 & 22 & 222 \\
Farm & Male & 10 & 84 & 7 & 101 \\
village G & Female & 15 & 90 & 16 & 121 \\
& Total & 25 & 174 & 23 & 222 \\
Farm & Male & 10 & 105 & 26 & 141 \\
village H & Female & 9 & 108 & 49 & 166 \\
& Total & 19 & 213 & 75 & 307 \\
Farm & Male & 10 & 77 & 17 & 104 \\
& Female & 9 & 106 & 25 & 140 \\
City S U & Total & 19 & 183 & 42 & 244 \\
& Male & 21 & 38 & 18 & 77 \\
& Female & 39 & 87 & 12 & 138 \\
Total & Total & 60 & 125 & 30 & 215 \\
\hline
\end{tabular}

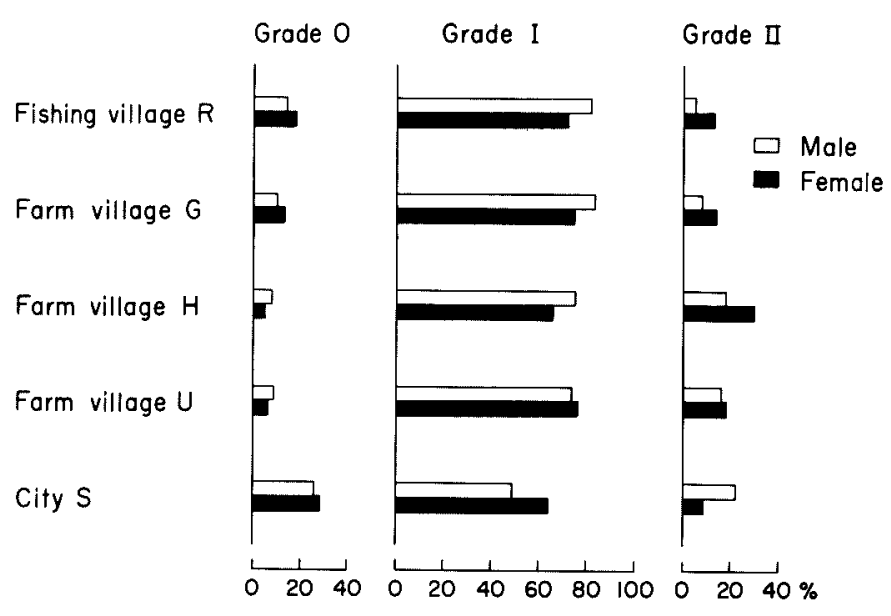

Fig. 3. Schematic representation of osteoporosis prevalence by area and sexes.

Osteoporosis and spinal crookedness. As shown in Table 3, the differences of the mean values of the above mentioned crookedness indices of the normal group between the fishing village $\mathrm{R}$ and the farm village $\mathrm{H}$ are not significant. However, these differences become very significant in the groups of the unevenly distorted trabecular lattice-work of grade I and in the groups of the 'ratten blind' form of grade II in the trabecular shadow. Accordingly, the indices indicate that the crookedness in the fishing village $R$ is much greater than that in the farm village $\mathrm{H}$. This shows, conversely speaking, that the osteoporotic changes in the farm village $H$ is much advanced than those in the fishing village $R$, even in the stage 
TABLE 2. $\chi^{2}$-Values of the osteoporosis prevalence between each combination of the two districts

\begin{tabular}{|c|c|c|c|c|c|}
\hline & $\begin{array}{c}\text { Fishing } \\
\text { village } \\
\mathbf{R}\end{array}$ & $\begin{array}{c}\text { Farm } \\
\text { village } \\
G\end{array}$ & $\begin{array}{c}\text { Farm } \\
\text { village } \\
\text { H. }^{\text {Filla }}\end{array}$ & $\begin{array}{l}\text { Farm } \\
\text { village } \\
\text { U }\end{array}$ & $\begin{array}{c}\text { City } \\
\text { S }\end{array}$ \\
\hline \multicolumn{6}{|c|}{ Males and females } \\
\hline $\begin{array}{l}\text { Fishing village } R \\
\text { Farm village } G \\
\text { Farm village } H \\
\text { Farm village } U \\
\text { City } \mathrm{S}\end{array}$ & - & $\begin{array}{c}2.30 \\
-\end{array}$ & $\begin{array}{c}27.74^{\ddagger} \\
1880_{+}^{\ddagger} \\
-\end{array}$ & $\begin{array}{c}11.54^{\dagger} \\
559 \\
4.47 \\
-\end{array}$ & $\begin{array}{l}1242 \ddagger \\
23.87^{\ddagger}+ \\
4887^{\ddagger} \\
3251 \ddagger \\
-\end{array}$ \\
\hline \multicolumn{6}{|c|}{ Males } \\
\hline $\begin{array}{l}\text { Fishing village } R \\
\text { Farm village } G \\
\text { Farm village } H \\
\text { Farm village } U \\
\text { City } S\end{array}$ & - & $\begin{array}{c}0.90 \\
-\end{array}$ & $\begin{array}{l}\text { 8. } 56^{*} \\
6.68^{*} \\
-\end{array}$ & $\begin{array}{c}5.52 \\
4.43 \\
0.62 \\
-\end{array}$ & $\begin{array}{l}1716^{\ddagger} \\
23.31^{\ddagger} \\
19.69^{\ddagger} \\
13.44^{+} \\
-\end{array}$ \\
\hline \multicolumn{6}{|c|}{ Females } \\
\hline $\begin{array}{l}\text { Fishing village } R \\
\text { Farm village } G \\
\text { Farm village } H \\
\text { Farm village } U \\
\text { City } S\end{array}$ & - & $\frac{1.24}{-}$ & $\begin{array}{c}2979^{+} \\
13.20^{+} \\
-\end{array}$ & $\begin{array}{l}900 \dagger \\
344 \\
5.65 \\
-\end{array}$ & $\begin{array}{l}5.48 \\
10.23 \dagger \\
41.43_{+}^{+} \\
25.25_{\ddagger}^{+} \\
-\end{array}$ \\
\hline
\end{tabular}

TABLE 3. Mean of crookedness indices according to osteoporotic changes in farm village $H$ and fishing village $R$

\begin{tabular}{|c|c|c|c|c|c|c|c|c|}
\hline \multirow{2}{*}{$\begin{array}{l}\text { Crooked- } \\
\text { ness }\end{array}$} & \multirow{2}{*}{$\begin{array}{l}\text { Osteo- } \\
\text { porosis }\end{array}$} & \multicolumn{3}{|c|}{ Farm village $H$} & \multicolumn{3}{|c|}{ Fishing village $R$} & \multirow{2}{*}{$\begin{array}{l}\text { Significance } \\
\text { level of the } \\
\text { difference }\end{array}$} \\
\hline & & $\mathrm{N}$ & $\mathbf{M}_{ \pm \text {S.E. }}$ & S.D. & $\mathrm{N}$ & $M_{ \pm \text {S.E. }}$ & S.D. & \\
\hline \multirow{3}{*}{$\begin{array}{c}\text { Kyphotic } \\
\text { index }\end{array}$} & $\mathrm{O}$ & 18 & $5.94 \pm 0.58$ & 2.49 & 33 & 5. $86 \pm 0.42$ & 2.44 & - \\
\hline & $\mathrm{I}$ & 209 & $6.16 \pm 0.15$ & 2.31 & 125 & $7.00 \pm 0.23$ & 2. 68 & $\mathrm{p}<0.01$ \\
\hline & II & 75 & $7.56 \pm 0.37$ & 3. 21 & 17 & 9. $73 \pm 0.81$ & 3. 55 & $\mathrm{p}<0.05$ \\
\hline Maximal & 0 & 18 & $354 \pm 1.60$ & 6. 82 & 33 & $321 \pm 1.54$ & 8. 88 & - \\
\hline kyphotic & $\mathbf{I}$ & 209 & $34.4 \pm 0.64$ & 9.28 & 125 & $36.4 \pm 064$ & 7. 20 & $\mathbf{p}<0 \quad 05$ \\
\hline position & II & 17 & $36.7 \pm 1.22$ & 10.60 & 17 & $42.5 \pm 155$ & 6.41 & $\mathbf{p}<0.05$ \\
\hline \multirow{3}{*}{$\begin{array}{l}\text { Lordotic } \\
\text { index }\end{array}$} & 0 & 18 & $1.80 \pm 0.26$ & 1.10 & 33 & $2.59 \pm 027$ & 1.58 & $\mathrm{p}<0.05$ \\
\hline & I & 209 & $2.03 \pm 0.09$ & 1.33 & 125 & $1.76 \pm 0.11$ & 1.25 & - \\
\hline & II & 17 & $1.58 \pm 0.16$ & 1.40 & 17 & $0.72 \pm 0.17$ & 0.71 & $p<0.01$ \\
\hline Maximal & $\mathrm{O}$ & 18 & $89.6 \pm 1.06$ & 4. 52 & 33 & $88.0 \pm 1.04$ & 6.00 & - \\
\hline lordotic & $I$ & 209 & $89.8 \pm 043$ & 6.52 & 125 & $905 \pm 049$ & 546 & 一 \\
\hline position & II & 17 & $91.8 \pm 089$ & 7. 72 & 17 & $960 \pm 1.42$ & 5. 86 & $\mathrm{p}<0.05$ \\
\hline
\end{tabular}

when the spinal crookedness is not so distinct.

Nutritional intake in the different districts. The nutriment intake in these five districts were drawn from the data of the National Nourishment Survey (Bureau of Public Health, Welfare Ministry of Japan 1971), if available, but when these 
TABLE 4. Per day per capita nutritional intake at different districts

\begin{tabular}{l|c|c|r|r|r}
\hline & $\begin{array}{c}\text { Fishing } \\
\text { village R }\end{array}$ & $\begin{array}{c}\text { Farm } \\
\text { village G }\end{array}$ & $\begin{array}{c}\text { Farm } \\
\text { village H }\end{array}$ & $\begin{array}{c}\text { Farm } \\
\text { village U }\end{array}$ & City S \\
\hline Year of survey & 1967 & 1970 & 1967 & 1969 & 1970 \\
Number of households & 50 & 32 & 58 & 47 & 35 \\
\hline Calorie (Cal) & 2,465 & 2,682 & 2,468 & 2,419 & 2,909 \\
Total protein (g) & 86 & 91 & 81 & 83 & 91 \\
Animal protein (g) & 40 & 31 & 29 & 33 & 43 \\
A/T protein ratio (\%) & 46.5 & 34.6 & 35.7 & 402 & 477 \\
Fat (g) & 45 & 48 & 41 & 48 & 68 \\
Carbohydrate (g) & 431 & 461 & 462 & 392 & 362 \\
Calcium (mg) & 625 & 601 & 5.2 & 532 & 633 \\
Iron (mg) & - & - & 14.9 & 161 & 142 \\
V. A efficiency (I.U.) & 2,099 & 3,203 & 882 & 1,150 & 1,857 \\
Vitamin B (mg) & 1.00 & 1.25 & 101 & 0.96 & 1.47 \\
Vitamin B (mg) & 091 & 1.18 & 1.09 & 1.03 & 0.93 \\
Vitamin C (mg) & 93 & 127 & 79 & 79 & 126
\end{tabular}

were unavailable nutritional survey was processed by ourselves in the same manner as employed in the above mentioned survey. The foodstuffs of continuous five days in every households were surveyed in terms of weight basis, and the nutrient intake was calculated according to the Japanese food composition table. The mean values of nutritional intake was expressed per capita per day for each district. As seen in Table 4, the nutrient intake advanced as the year passed. Yet the regional difference is much distinct among the fishing village, the farm village and the city. Differences in intake of animal protein, animal/total protein ratio and calcium intake seem to be most distinct regional difference.

\section{Discussion}

Since Albright and his colleagues presented the osteoporosis as a clinical entity, much attention has been paid to this disease by many clinicians. As to the etiology of osteoporosis, there have been numerous theories assuming its close relation to, for instance, postmenopausal reduction of anabolic and other hormons (Reifenstein and Albright 1947), nutritional deficiency of calcium (Nordin 1961), other metabolic dysfunctions in gastro-intestinal tract (Caniggia et al. 1963) or kidney (Bhandarkar and Nordin 1962), and so on.

On the other hand, some investigators have been trying to elucidate the etiology by the epidemiologic procedures. Itami et al. (1966) have shown that osteoporosis prevalence was much smaller in fishing village $(4.9 \%$ ) as compared to that in farm village $(16.3 \%)$ by the roentgenographic examination. Bernstein et al. (1966) reported that regional difference was observed in North Dakota with respect to osteoporosis prevalence among the people aged over 45 who lived in two areas where the fluoride content of water supply were high and low, namely, evidence of osteoporosis was significantly higher in low-fluoride area and this was especially evident among women. It was also noticed that visible calcification of the aorta was significantly higher in low-fluoride area, particularly among men. 
Kamiyama et al. (1968) found significantly higher prevalence of osteoporosis among hypertensive than among non-hypertensive patients, especially among females, after the examination of lumber vertebral bodies by direct enlargement roentgenograms in the out-patient clinic of a hospital. Guggenheim et al. (1971) recently observed that among 1,463 ambulatory outpatients of an Israeli hospital, the subjects of North African and Asian origins had significantly more osteoporosis than those of European, North American, or Israeli origins.

The mortality from cerebrovascular lesions in Tohoku area, the north-eastern part of Japanese mainland, is higher among inland farm districts and lower among the rocky coast fishing districts facing the Pacific Ocean (Kaneta et al. 1964). As for the nutritional intake, inhabitants of the farm districts were inferior of protein, fat, calcium, phosphor, iron and vitamins of B complex and C. Especially, calcium intake could influence the prevalence of both osteoporosis and cerebrovascular diseases.

In the present study, osteoporosis prevalence in the five different districts were compared with particular concerns to its relation to the calcium storage in bone which should be influenced by different nutritional intake. These comparisons have revealed that the regional difference of osteoporosis prevalence is higher in the inland farm villages and lower in the coastal fishing village as well as in the city and that the observed regional difference is closely related with nutritional intake, especially of calcium and animal protein, among the people. This relationship was far closer among female subjects than among male. This is in accord with the cases of the survey of hip fractures (Bollet et al. 1965), osteoporosis prevalence in high- and low-fluoride areas (Bernstein et al. 1966), in hypertensive patients (Kamiyama et al. 1968), and in Israeli patients (Guggenheim et al. 1971).

In Japanese rural districts, elder people who have crooked posture are still seen occasionally. This kind of spinal crookedness was revealed to be more frequent and more advanced in a farm village than in a fishing village (Abe, 1971). Also the osteoporotic change is much advanced in the farm village than in the fishing village when compared at the stage showing the same degree of spinal crookedness. The regional difference hitherto observed in the osteoporosis prevalence and spinal crookedness among senile inhabitants of farm, fishing and rural districts seems to reflect the differences in their habitual food intake. Namely, too much biased diet for polished rice in farm villages tends to result in lack in minerals, vitamins and animal proteins, which are important for the metabolic events in bone tissues. Besides the nutritional factors, natural and ecological conditions such as sunshine and labor habits should also be considered for the regional difference in the osteoporosis prevalence.

\section{References}

1) Abe, S. (1971) Epidemiological studies on the different occurrence of senile crookedness in farm and fishing villages. Human Ecol. \& Race Hyg. (Jap.), 37, 35-58.

2) Barnett, E. \& Nordin, E.B.C. (1960) The radiological diagnosis of osteoporosis. Clin. Radiol., 11, 166-174. 
3) Bernstein, D.S., Sadowsky, N., Hegsted, D.M., Guri, C.D. \& Stare, F.J. (1966) Prevalence of osteoporosis in high- and low-fluoride areas in North Dakota. J. Amer. med. Ass. 198, 499-504.

4) Bhandarkar, S.D. \& Nordin, B.E.C. (1962) Effect of low-calcium diet on urinary calcium in osteoporosis. Brit. med. $J ., 1,145-147$.

5) Bollet, A.J., Engh, G. \& Parson, W. (1965) Epidemiology of osteoporosis. Sex and race incidence of hip fractures. Arch. intern. Med., 116, 191-194.

6) Bureau of Public Health, Welfare Ministry of Japan (1971), Present State of National Nutrition in 1968 (Jap.), Daiichi-Shuppan, Tokyo.

7) Caniggia, A., Gennari, C., Binachi, V. \& Guideri, R. (1963) Intestinal absorption of ${ }^{45} \mathrm{Ca}$ in senile osteoporosis. Acta med. scand., 173, 613-617.

8) Guggenheim, K., Menczel, J., Reshef, A., Schwartz, A., BenMenachem, Y., Bernstein, D.S., Hegsted, D.M. \& Stare, F.J. (1971) An epidemiological study of osteoporosis in Israel. Arch. environ. Hlth, 22, 259-264

9) Itami, Y., Ohata, S., Nakamura, J. \& Omori, S., (1966) Epidemiology and clinic of osteoporosis, In: Osteoporosis (Jap.), edited by I. Miki, Nankodo, Tokyo, p. 43.

10) Kamiyama, S., Kobayashi, S., Takahashi, E., Wakamatsu, E \& Kurashina, T. (1968) Osteoporosis in hypertensive and non-hypertensive subjects. Tohoku J. exp. Med., 94, 225-230.

11) Kaneta, S., Ishiguro, K., Kobayashi, S. \& Takahashi, E. (1964) An epidemiological study on nutrition and cerebrovascular lesions in Tohoku area of Japan. Tohoku J. exp. Med., 83, 398-408.

12) Kobayashi, J. (1957) On geographical relationship between the chemical nature of river water and death-rate from apoplexy. Berichte des Ohara Instituts für landwirtschaftliche Biologie, 11, 12-21.

13) Nordin, B.E.C. (1961) The pathogenesis of osteoporosis. Lancet, 1, 1011-1015.

14) Reifenstein, E.C. \& Albright, F. (1947) The metabolic effects of steroid hormones in osteoporosis $J$. clin. Invest., 26, 24-56.

15) Wakamatsu. E. (1966) Pathology of osteoporosis. In: Osteoporosis (Jap.), edited by I. Miki, Nankodo, Tokyo, p. 1.

16) Wakamatsu, E., Sato, K. \& Kusakabe, A. (1971) Relationship between roentgenographic and histological findings of osteoporosis. Nihon Seikei-geka Gakkai Sokai Syoroku (Jap.), p. 28

17) World Health Organization (1967) Epidem. vital Statist. Rep., Geneva.

18) World Health Organization (1962) Report of an WHO/FAO Expert Group. 'Calcium requirements' No. 230, Geneva. 